\title{
РЕГИОНАЛЬНЫЕ ДИСПРОПОРЦИИ И РИСКИ ПРОСТРАНСТВЕННОГО РАЗВИТИЯ В РЕСПУБЛИКЕ БЕЛАРУСЬ*
}

\section{Е.А. Рожковская ${ }^{* *}$}

Рассматриваются основные диспропорции и проблемы пространственного развития белорусской экономики в 2014-2020 гг. Отмечается, что сложившиеся региональные дисбалансы и увеличивающаяся дифференциация между регионами по уровню социально-экономического развития выступают серьезным фактором риска усиления социального неравенства в стране и замедления экономической динамики в кратко- и долгосрочной перспективе. Предложены основные направления совершенствования региональной экономической политики, позволяющие сократить существующие пространственные диспропорции и разрывы в уровне развития регионов Беларуси.

Ключевые слова: белорусская экономика, регионы, региональные диспропорции, валовой региональный продукт, риски пространственного развития, региональная политика.

JEL-классификация: R10, R12, R58, E61.

DOI: $10.46782 / 1818-4510-2021-4-55-71$

Материал поступил 18.11.2021 2.

Развитие белорусской экономики в последние годы сопряжено с нарастанием и обострением многочисленных рисков и угроз как внешнего, так и внутреннего характера. Наиболее значимыми вызовами социально-экономического развития республики, потенцирующими риски замедления экономического роста, являются несбалансированность региональной динамики и диспропорции пространственного развития, демонстрирующие тенденцию к усилению (Фатеев, 2012; Берченко, 2020). О возрастании значимости проблем регионального развития и внимания органов государственного управления к их решению свидетельствует разработанная «Программа социально-экономического развития Республики Беларусь на 2021-2025 гг.» ${ }^{1}$, ключевым при-

1 Указ Президента Республики Беларусь от 29 июля 2021 г. № 292 «Об утверждении Программы социальноэкономическогоразвития Республики Беларусь на 20212025 годы». оритетом которой являются «Сильные регионы», а также принятые программы и планы развития отдельных территорийㄹ․

Проблема несбалансированного пространственного развития не является уникальной для Беларуси: все страны в той или иной степени сталкиваются с необходимостью ее решения. Однако вследствие радикально различающихся исторических, природно-климатических, демографических и экономических условий развития государств универсальных подходов к ее урегулированию не существует. Вместе с тем чрезмерное нарастание региональных диспропорций вызывает риски усиления межрегиональной дифференциации и социаль-

${ }^{2}$ Постановление Совета Министров Республики Беларусь «План развития отдельных регионов» от 09.10.2019 г. № 689 (в редакции постановления Совета Министров Республики Беларусь от 01.03.2021 г. № 119); Указ Президента Республики Беларусь «О развитии Оршанского района Витебской области» от 31.12 .2018 г. № 506.

* Статья подготовлена при финансовой поддержке Белорусского республиканского фонда фундаментальных исследований в рамках научного проекта «Оценка рисков устойчивого развития регионов: выявление причин и источников их появления и разработка предложений по предотвращению».

** Рожковская Екатерина Агеевна (E.Rozhkovskaya@mail.ru), кандидат экономических наук, доцент, Белорусский государственный экономический университет (г. Минск, Беларусь). https://orcid.org/0000-0002-0089-2331 
ного неравенства, потери стимулов для развития регионов и замедления роста национальной экономики ${ }^{3}$. Неоднородность распределения экономического потенциала на территории страны, формирование агломерационных полюсов роста, «стягивающих» экономическую активность соседних регионов, ведут к деформации экономического пространства, росту социальной напряженности в обществе, подрывая возможности устойчивого развития экономики (Минакир, 2019; Крюков, Коломак, 2021).

Острота обозначенных проблем обуславливает необходимость своевременного выявления диспропорций регионального развития, анализа причин их возникновения, оценки степени их значимости и остроты с точки зрения влияния на национальную экономику. Это позволит выработать взвешенные меры экономической политики, направленные на сглаживание территориальных диспропорций, решение проблем несбалансированного пространственного развития и сокращение различий в уровне развития регионов. Цель данной статьи - на основе анализа ключевых макроэкономических показателей белорусской экономики в региональном разрезе за 2014-2020 гг. выявить основные региональные диспропорции и связанные с ними риски пространственного развития Республики Беларусь, разработать на этой основе предложения, направленные на смягчение негативных последствий чрезмерной дифференциации социально-экономического развития регионов.

\section{Динамика регионального развития в Республике Беларусь}

В 2014-2020 гг. пространственное развитие Беларуси характеризовалось неравномерностью и постепенным замедлением экономической динамики. В анализируемом периоде совокупный объем ВВП республики сократился в реальном выражении на 0,4 п. п. к уровню 2014 г., а его среднегодовые темпы роста составили 99,9\%. При этом динамика развития регионов была крайне разнонаправленной: разброс темпов прироста их ВРП со-

${ }^{3}$ Социальная политика в России: проблемы и решения: научный доклад. 2021. URL: https://ecfor.ru/wp-content/ uploads/2021/04/sotsialnaya-politika-v-rossii-problemy-iresheniya.pdf ставил от $+9,5 \%$ в Минской области до $-8,6 \%$ в Витебской области.

В целом замедление экономического роста наблюдалось в пяти из семи регионов республики - в 2020 г. объем их ВРП (за исключением Минской и Брестской областей) так и не достиг уровня докризисного 2014 г. В результате в исследуемом периоде положительное влияние на формирование экономической динамики республики в региональном разрезе оказали Брестская и Минская области, обеспечив вклад в формирование процентного изменения ВВП Беларуси на уровне 0,33 и 1,43 п. п. соответственно. Отрицательный вклад в динамику ВВП республики внес ВРП Витебской (-0,65 п. п.), Гомельской области (-0,48 п. п.), г. Минска (-0,25 п. п.), Гродненской $(-0,09$ п. п.) и Могилевской области (-0,16 п. п.), а также нераспределенная часть ВРП (-0,53 п. п.) (рис. 1).

Отмеченное замедление экономической динамики в стране и на уровне регионов, с одной стороны, является результатом действия уже реализовавшихся факторов риска как внутреннего, так и внешнего характера, в первую очередь кризиса 20152016 гг., связанного с рецессией российской экономики в результате обвала мировых цен на нефть и введением западными

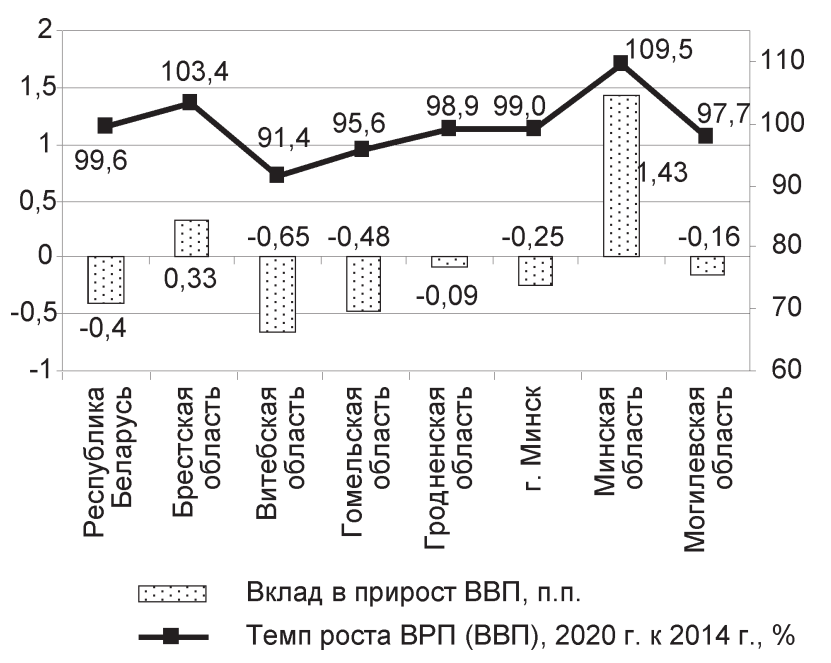

Рис. 1. Темп роста ВРП регионов и их вклад в формирование процентного прироста ВВП Республики Беларусь в целом за 2014-2020 гг., \%

Источник. Рассчитано на основе: Национальные счета Республики Беларусь, 2021: стат. сборник. 2021. Минск: Национальный статистический комитет Республики Беларусь. 
странами антироссийских санкций, а также резкого падения мировой экономики в 2020 г. на 3,5\% ${ }^{4}$ к уровню 2019 г. вследствие пандемии коронавируса. С другой стороны, длительное сохранение отрицательных темпов роста экономик регионов само по себе выступает мощным фактором усиления долговременных рисков и угроз, обеспечивая переход экономики к суженному типу воспроизводства и провоцируя усиление межрегиональной дифференциации за счет усиления разрыва между растущими и стагнирующими регионами.

Вместе с тем существенное влияние на формирование динамики регионального развития оказывали не только внешние по отношению к региону факторы, но и внутренние, обусловленные особенностями развития территорий.

Вообще, темпы роста развития региона являются результирующей воздействия трех компонентов: общенациональной динамики, отражающей влияние проводимой макроэкономической политики и формирующей общие условия функционирования экономики конкретной территории; структурных факторов, связанных с особенностями или сдвигами в отраслевой структуре региона; собственно региональной динамики, отражающей воздействие местных факторов роста (качества человеческого капитала, агломерационных эффектов и т. д.) и/или возможных шоков локального характера. Для оценки раздельного вклада (эффекта) названных составляющих в формирование ВРП регионов республики обычно используется метод структурных сдвигов (shift-share analysis), являющийся распространенным инструментом анализа региональной динамики (Михеева, 2013; Knudsen, 2000; Mondal, 2009). В основу метода положено балансовое тождество, описывающее прирост результативного показателя регионального развития, в качестве которого обычно выступает ВРП, за счет трех компонентов:

$$
\Delta E_{i r}=N S_{i r}^{t}+M S_{i r}^{t}+R S_{i r}^{t}
$$

${ }^{4}$ Global Economic Prospects. 2021. A World Bank Group. Flagship Report. URL: https://openknowledge.worldbank.org/ bitstream/handle/10986/35647/9781464816659.pdf где $\Delta E_{i r}-$ прирост результирующего показателя регионального развития;

$N S_{i r}^{t}-$ компонент общенациональной динамики;

$M S_{i r}^{t}$ - компонент отраслевой структуры (отраслевой сдвиг);

$R S_{i r}^{t}$ - компонент регионального развития (региональный сдвиг).

Влияние динамики национального развития $\left(N S_{i r}^{t}\right)$ для вида деятельности $i$ в регионе $r$ в году $t$ рассчитывается по формуле:

$$
N S_{i r}^{t}=\sum\left(E_{i r}^{t-1} \cdot E_{N}^{t} / E_{N}^{t-1}\right)
$$

Уравнение (2) отражает влияние на прирост ВРП общего состояния и динамики развития национальной экономики, при этом закладывается предположение, что темп роста регионального показателя по каждому виду деятельности пропорционален росту общенационального показателя - ВВП $\left(E_{N}\right)$.

Влияние компонента структурных сдвигов $\left(M S_{i r}^{t}\right)$ обусловлено особенностями отраслевой структуры валовой добавленной стоимости (ВДС) на данной территории и отражает эффект, вызванный преобладанием в структуре производства региона отраслей, растущих темпами, опережающими общенациональную динамику роста:

$$
M S_{i r}^{t}=\sum\left(E_{i r}^{t-1} \cdot\left(\frac{E_{i N}^{t}}{E_{i N}^{t-1}}-\frac{E_{N}^{t}}{E_{N}^{t-1}}\right)\right) .
$$

Эффект регионального сдвига отражает влияние на ВРП факторов региональной конкурентоспособности, оцениваемых на основе разности между отраслевыми темпами роста ВДС на национальном и региональном уровнях:

$$
R S_{i r}^{t}=\sum\left(E_{i r}^{t-1} \cdot\left(\frac{E_{i r}^{t}}{E_{i r}^{t-1}}-\frac{E_{i N}^{t}}{E_{i N}^{t-1}}\right)\right) .
$$

Уравнение (4) позволяет определить влияние региональных факторов роста, не связанных напрямую с общей экономической динамикой в стране, и отражает эффект, вызванный наличием в регионе видов деятельности, растущих быстрее или медленнее по сравнению с теми же отраслями по экономике в целом.

Результаты расчетов вклада общенациональной, отраслевой и региональной компонент на темпы прироста ВРП по регио- 
нам Республики Беларусь в целом за 20142020 гг. представлены в табл. 1.

Расчеты показывают, что влияние национального эффекта на динамику ВРП регионов в 2014-2020 гг. было отрицательным, что объясняется сдержанной экономической активностью в стране и вялотекущими темпами роста белорусской экономики в исследуемом периоде. При этом негативное воздействие национальной компоненты на развитие регионов не было определяющим - ее вклад в формирование прироста ВРП регионов колебался в среднем на уровне около 10\% (за исключением Гродненской области и г. Минска, в которых национальная составляющая определяла около $40 \%$ прироста регионального продукта).

При этом только в Минской и Брестской областях отрицательный вклад национальной динамики компенсировался положительным влиянием региональных факторов роста. В остальных регионах определяющее влияние на формирование процентного изменения ВРП оказывала негативная региональная динамика.

\section{Структурные диспропорции и риски регионального развития Беларуси}

Региональные ограничения экономического роста в стране в основном связаны с географически и исторически обусловленной неоднородностью распределения производственных ресурсов и экономического потенциала на территории республики, сложившейся структурой производства и занятости, действием агломерационных эффектов, усиливающим перелив капитала и трудовых ресурсов в активно растущие регионы, что притягивает и сосредотачивает в них ресурсы и экономическую активность близлежащих территорий. Эти процессы обуславливают формирование и устойчивый характер диспропорций в региональной структуре экономики, чрезмерное нарастание которых усиливает риски пространственного развития государства.

К числу наиболее значимых региональных диспропорций, определяющих возможности пространственного развития Беларуси, относятся следующие:

концентрация демографического и трудового потенциала в относительно богатых и успешных регионах;

усиливающаяся дивергенция между регионами по общеэкономическому уровню развития - ВРП, экспорту, инвестициям в основной капитал, а также увеличение разрыва в уровне производительности труда между регионами;

нарастание межрегиональной дифференциации в уровне жизни и доходах населения, усиление имущественного неравенства на региональном уровне, сохранение значительного разрыва между регионами в уровне потребления товаров и услуг.

Одним из наиболее значимых факторов несбалансированного регионального развития в стране является сокращение численности населения и количества занятых в экономике и усиление конщентращии демографического и трудового потенциала в быстроразвивающихся регионах - г. Минске и Минской области. Так, за 2014-2020 гг. численность населения Беларуси сократи-

Вклад в процентный прирост ВРП регионов факторов национальной

Таблица 1 и региональной динамики, 2014-2020 гг., \%

\begin{tabular}{|l|c|c|c|c|c|}
\hline \multicolumn{1}{|c|}{ Регион } & $\mathrm{NS}$ & $\mathrm{MS}+\mathrm{RS}$ & $\mathrm{MS}$ & $\mathrm{RS}$ & $\begin{array}{c}\text { Прирост ВРП, 2020 г. } \\
\text { к уровню 2014 г. }\end{array}$ \\
\hline Брестская область & $-0,4$ & 3,8 & $-0,2$ & \multicolumn{1}{c|}{4,0} & 3,4 \\
\hline Витебская область & $-0,4$ & $-8,2$ & $-0,37$ & $-7,83$ & $-8,6$ \\
\hline Гомельская область & $-0,4$ & $-4,0$ & $-0,85$ & 3,15 & $-4,4$ \\
\hline Гродненская область & $-0,4$ & $-0,7$ & $-0,27$ & $-0,43$ & $-1,1$ \\
\hline г. Минск & $-0,4$ & $-0,6$ & 0,01 & $-0,61$ & $-1,0$ \\
\hline Минская область & $-0,4$ & 9,9 & $-0,04$ & 9,94 & 9,5 \\
\hline Могилевская область & $-0,4$ & $-1,9$ & 0,34 & $-2,24$ & $-2,3$ \\
\hline
\end{tabular}

Источник. Рассчитано на основе: Национальные счета Республики Беларусь, 2021: стат. сборник. 2021. Минск: Национальный статистический комитет Республики Беларусь; Регионы Республики Беларусь. Социально-экономические показатели, 2021 (том 1): стат. сборник. 2021. Минск: Национальный статистический комитет Республики Беларусь. 
лась более чем на 103 тыс. чел. Опережающее уменьшение численности населения в Витебской, Могилевской и Гомельской областях было отчасти компенсировано его ростом в относительно богатых регионах г. Минске и Минской области.

Сокращение численности занятых в экономике в абсолютном выражении отмечалось во всех без исключения регионах и составило за 2014-2020 гг. 230,9 тыс. чел., при этом наиболее интенсивно количество занятых уменьшалось в Витебской, Гомельской и Гродненской областях. В то же время сохраняется тенденция относительного увеличения доли занятых в столичном регионе - прирост в г. Минске составил 1,2 п. П., в Минской области - 0,6 п. п., что свидетельствует об усилении тенденции неоднородности размещения трудовых ресурсов в стране на территориальном уровне (табл. 2).

Сокращение численности населения и количества занятых в экономике не только выступает источником угроз в области демографической безопасности страны ${ }^{5}$, но и является фактором, способствующим замедлению экономической активности в регионе, сжатию потребительского и инвестиционного спроса и ухудшению его структурных ха-

${ }^{5}$ В Витебской и Могилевской областях соотношение численности умерших и родившихся на 1000 чел. населения составило в 2019 г. 1,82 и 1,5 раза соответственно, коэффициент депопуляции по Беларуси в целом составляет 1,38 при его пороговых значениях демографической безопасности не более 1 . рактеристик, падению реальных доходов населения, оттоку наиболее квалифицированных кадров в регионы с более достойными условиями труда, как правило - крупные города и агломерации.

Локализация демографических и трудовых ресурсов запускает действие агломерационных эффектов, которые наряду с увеличением объемов производства, доходов и совокупного спроса вызывают усиление пространственной неравномерности распределения ресурсов. Действием описанных эффектов объясняется концентрация демографического и экономического потенциала республики в г. Минске и Минской области (табл. 3).

Так, в 2014-2020 гг. отмечалось увеличение суммарного удельного веса г. Минска и Минской области в пространственном распределении ВРП, численности населения, розничного товарооборота и других макропараметров. На их долю приходилось более 35\% производимой в стране промышленной продукции, 45\% объема инвестиций и $50 \%$ экспорта товаров. При этом обращают на себя внимание значительные сдвиги в региональной структуре товарного экспорта и инвестиций в основной капитал в направлении увеличения доли Минской области, которые уже вызвали увеличение удельного веса промышленного производства в данном регионе и в перспективе, вероятно, приведут к росту доли производимого ВРП.

Таблица 2

Региональная структура численности и занятости населения Республики Беларусь, 2014-2020 гг., \%

\begin{tabular}{|c|c|c|c|c|c|c|c|c|}
\hline \multirow{3}{*}{ Регион } & \multicolumn{4}{|c|}{ Численность населения } & \multicolumn{4}{|c|}{ Численность занятых } \\
\hline & \multicolumn{2}{|c|}{ Структура } & \multirow[b]{2}{*}{$\begin{array}{c}\text { Изменение, } \\
\text { п. п. }\end{array}$} & \multirow{2}{*}{$\begin{array}{c}\text { Темп роста } \\
2020 \text { г. к уровню } \\
2014 \text { г., \% }\end{array}$} & \multicolumn{2}{|c|}{ Структура } & \multirow[b]{2}{*}{$\begin{array}{c}\text { Изменение, } \\
\text { п. п. }\end{array}$} & \multirow{2}{*}{$\begin{array}{c}\text { Темп роста } \\
2020 \text { г. } \\
\text { к уровню } \\
2014 \text { г., \% } \\
\end{array}$} \\
\hline & 2014 & 2020 & & & 2014 & 2020 & & \\
\hline Брестская обл. & 14,5 & 14,3 & $-0,2$ & 97,5 & 13,7 & 13,5 & $-0,2$ & 93,9 \\
\hline Витебская обл. & 12,5 & 12,0 & $-0,5$ & 94,7 & 11,8 & 11,1 & $-0,7$ & 89,7 \\
\hline Гомельская обл. & 15,0 & 14,7 & $-0,3$ & 97,2 & 13,9 & 13,5 & $-0,4$ & 92,7 \\
\hline $\begin{array}{l}\text { Гродненская } \\
\text { обл. }\end{array}$ & 11,1 & 10,9 & $-0,2$ & 97,3 & 10,9 & 10,6 & $-0,3$ & 92,2 \\
\hline г. Минск & 20,6 & 21,5 & $+0,9$ & 103,2 & 23,9 & 25,1 & $+1,2$ & 99,4 \\
\hline Минская обл. & 15,1 & 15,8 & $+0,7$ & 103,0 & 15,3 & 15,9 & $+0,6$ & 98,2 \\
\hline $\begin{array}{l}\text { Могилевская } \\
\text { обл. }\end{array}$ & 11,2 & 10,8 & $-0,4$ & 96,0 & 10,5 & 10,3 & $-0,2$ & 92,9 \\
\hline
\end{tabular}

Источник. Регионы Республики Беларусь. Социально-экономические показатели, 2021 (том 1): стат. сборник. 2021. Минск: Национальный статистический комитет Республики Беларусь. 
Структура основных макроэкономических показателей Республики Беларусь в региональном разрезе, 2014-2020 гг., \%

\begin{tabular}{|l|c|c|c|c|c|c|c|r|r|r|}
\hline \multirow{2}{*}{ Регион } & \multicolumn{2}{|c|}{ ВВП } & \multicolumn{2}{|c|}{$\begin{array}{c}\text { Промышленное } \\
\text { производство }\end{array}$} & $\begin{array}{c}\text { Розничный } \\
\text { товарооборот }\end{array}$ & \multicolumn{2}{|c|}{$\begin{array}{c}\text { Инвестиции } \\
\text { в основной } \\
\text { капитал }\end{array}$} & \multicolumn{2}{|c|}{$\begin{array}{c}\text { Экспорт } \\
\text { товаров }\end{array}$} \\
\cline { 2 - 14 } & 2014 & 2020 & 2014 & 2020 & 2014 & 2020 & 2014 & 2020 & 2014 & 2020 \\
\hline Брестская обл. & 9,7 & 9,5 & 10,4 & 11,9 & 12,5 & 12,2 & 10,8 & 11,2 & 7,0 & 9,0 \\
\hline Витебская обл. & 8,1 & 8,0 & 15,7 & 13,3 & 11,7 & 10,2 & 8,6 & 9,7 & 8,2 & 5,9 \\
\hline Гомельская обл. & 11,3 & 10,3 & 20,9 & 18,7 & 12,2 & 11,5 & 17,5 & 14,3 & 12,9 & 13,0 \\
\hline Гродненская обл. & 8,6 & 8,1 & 10,4 & 11,1 & 11,0 & 9,9 & 12,2 & 12,2 & 6,1 & 8,4 \\
\hline г. Минск & 24,9 & 27,6 & 16,1 & 16,1 & 29,4 & 30,5 & 23,7 & 19,3 & 36,6 & 28,9 \\
\hline Минская обл. & 15,1 & 14,9 & 17,5 & 19,8 & 14,3 & 17,1 & 18,5 & 26,3 & 21,7 & 24,5 \\
\hline Могилевская обл. & 7,2 & 6,6 & 9,1 & 9,1 & 8,9 & 8,6 & 8,5 & 6,9 & 6,2 & 6,6 \\
\hline
\end{tabular}

Примечание. Сумма элементов структуры по отдельным показателям не дает 100\%, что связано с особенностями расчета и представления региональной статистики, включающей значительную часть нераспределенной продукции (товаров, услуг) между областями.

Источник. Регионы Республики Беларусь. Социально-экономические показатели, 2021 (том 1): стат. сборник. 2021. Минск: Национальный статистический комитет Республики Беларусь.

Однако усиление неравномерности распределения ресурсов на территориальном уровне имеет ряд негативных последствий: возрастает зависимость экономической динамики от темпов роста регионов с высокой концентрацией экономического потенциала. При этом риски пространственного развития увеличиваются в случае высокой степени зависимости агломераций от внешнего спроса. В случае ухудшения внешнеэкономической ситуации замедление динамики в региональных центрах роста за счет глубоких межрегиональных отраслевых и производственных связей вызывает снижение темпов роста дру- гих территорий и страны в целом. На рис. 2 представлены результаты разложения процентного прироста ВВП Беларуси с позиций вклада в его динамику ВРП регионов, которые подтверждают определяющее влияние г. Минска и Минской области в формирование роста национальной экономики. Совокупный вклад этих регионов в процентный прирост ВВП составлял в 2014-2020 гг. в среднем около 60\%, при этом, как показывают рассчитанные коэффициенты эластичности, в этот период 1\%-й прирост ВРП г. Минска вызывал прирост экономики Беларуси на $0,75 \%$.

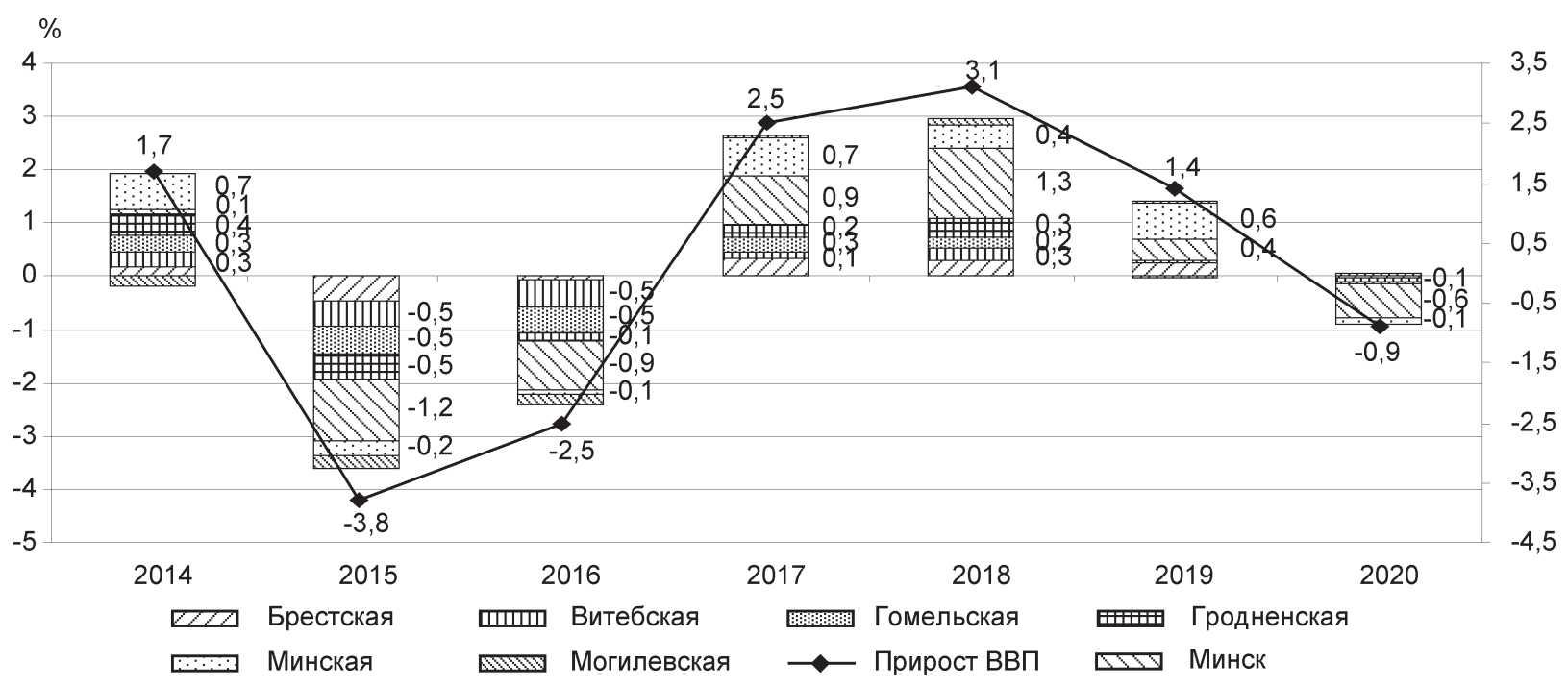

Рис. 2. Вклад ВРП регионов в формирование процентного прироста ВВП Республики Беларусь, 2014-2020 гг.

Источник. Рассчитано на основе: Национальные счета Республики Беларусь, 2021: стат. сборник. 2021. Минск: Национальный статистический комитет Республики Беларусь. 
Высокая степень зависимости национальной экономики от динамики развития регионов, чувствительных к действию внешних факторов (доля экспорта товаров и услуг в ВРП г. Минска и Минской области составляет более $80 \%$ ), обуславливает высокую волатильность общей экономической динамики, что подрывает возможности устойчивого развития регионов и страны в целом. Вместе с тем решение данной проблемы далеко не однозначно. Снизить зависимость экономики от динамики развития столичной агломерации возможно за счет усиления процессов диверсификации структуры производства и/или переноса производственного потенциала в другие регионы, как это предусматривает Национальная стратегия устойчивого развития на период до 2035 года ${ }^{6}$. Однако обратной стороной этого процесса может выступать снижение уровня специализации региона, вызывающее риски снижения продуктивности используемых ресурсов и производительности труда.

К числу наиболее значимых рисков, сдерживающих возможности роста белорусской экономики, относятся низкая производительность труда, которая составляет около $60 \%$ от уровня России и $15 \%$ - уровня стран Евросоюза. Сложившиеся тенденции сокращения занятости в Беларуси в значительной мере определяют уровень и динамику производительности труда по регионам. Анализ показал, что в Витебской и Гомельской областях отмечается усиление разрыва в

${ }^{6}$ URL: https://www.economy.gov.by/uploads/files/ ObsugdaemNPA/NSUR-2035-1.pdf уровне производительности труда по сравнению со среднереспубликанским: если в 2014 г. отношение ВРП к численности занятых в экономике составляло 74 и $77,7 \%$ от среднего уровня по стране, то в 2020 г. это соотношение уменьшилось до 71,8 и $76,4 \%$ соответственно (табл. 4). Основными причинами снижения производительности труда в этих регионах явились опережающие по сравнению со среднереспубликанскими темпы сокращения валового регионального продукта (91,4 и 95,6\% к уровню 2014 г.) и численности занятого населения $(89,7$ и $92,7 \%$ соответственно).

При этом обращает на себя внимание снижение производительности труда в г. Минске по сравнению со средним уровнем по стране. Если в 2014 г. ВРП на одного занятого превышал средний по республике показатель на 15,9 п. п., то в 2020 г. - уже только на 10 п. п., что косвенно свидетельствует об относительном уменьшении возможностей столичного региона выступать в качестве драйвера роста экономики в целом.

Вместе с тем сложившийся в отдельных регионах (Брестская, Витебская область) низкий уровень производительности труда во многом объясняется сформировавшейся в них неэффективной отраслевой структурой производства (табл. 5), характеризующейся низким удельным весом видов экономической деятельности, обладающих глубокой степенью переработки. Расчеты показывают, что в регионах-лидерах, имеющих самую высокую в республике производительность труда, г. Минске и Минской области, доля видов эко-

Таблица 4

Производительность труда по ВРП по регионам Беларуси, в сопоставимых ценах, 2014-2020 гг.

\begin{tabular}{|l|c|c|c|c|}
\hline \multirow{2}{*}{ Регион } & $\begin{array}{c}\text { Производительность } \\
\text { труда на 1 занятого } \\
\text { в экономике, } \\
\text { руб. в 2020 г. }\end{array}$ & \multicolumn{2}{|c|}{$\begin{array}{c}\text { Отношение регионального } \\
\text { уровня производительности } \\
\text { труда к среднему по стране, \% }\end{array}$} & $\begin{array}{c}\text { Рост/снижение } \\
\text { производительности } \\
\text { труда в 2020 г. } \\
\text { к уровню 2014 г., \% }\end{array}$ \\
\cline { 1 - 4 } Республика Беларусь & 34032 & 2014 & 2020 & 104,9 \\
\hline Брестская обл. & 23819 & 100,0 & 100,0 & 110,1 \\
\hline Витебская обл. & 24436 & 74,7 & 70,0 & 101,9 \\
\hline Гомельская обл. & 26003 & 77,7 & 71,8 & 103,1 \\
\hline Гродненская обл. & 25950 & 74,6 & 76,4 & 107,3 \\
\hline г. Минск & 37436 & 115,9 & 110,0 & 99,6 \\
\hline Минская обл. & 31953 & 88,4 & 93,9 & 111,5 \\
\hline Могилевская обл. & 21997 & 64,5 & 64,6 & 105,2 \\
\hline
\end{tabular}

Источник. Регионы Республики Беларусь. Социально-экономические показатели, 2021 (том 1): стат. сборник. 2021. Минск: Национальный статистический комитет Республики Беларусь. 


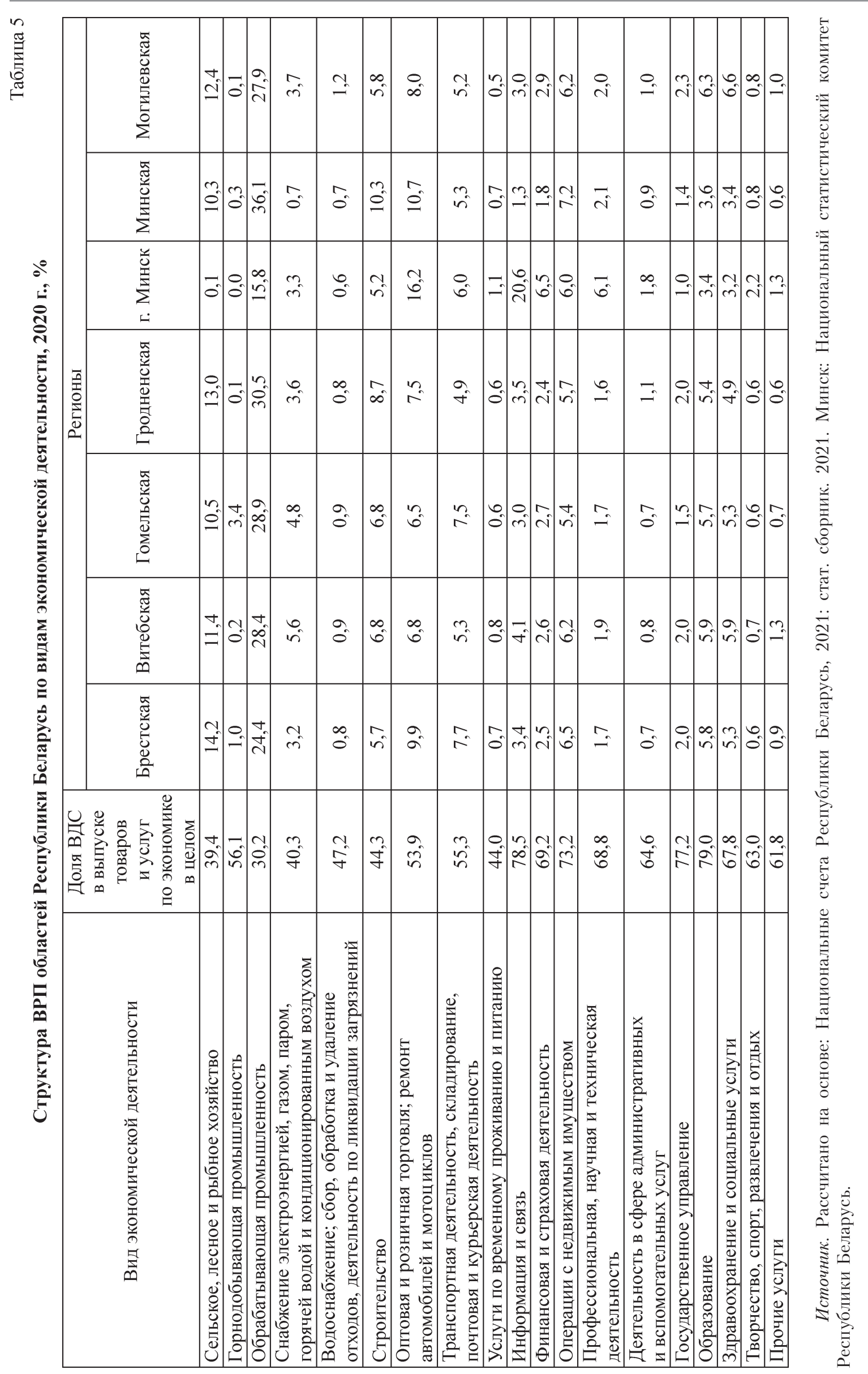


номической деятельности с высокой добавленной стоимостью составляет в их ВРП 63,6 и $67,9 \%$ соответственно, в то время как в регионах-аутсайдерах - Брестской и Витебской областях - всего 29,5 и 28,5\%.

В то же время низкая производительность труда в Могилевской области не может быть объяснена фактором нерациональной структуры производства - в составе ее ВРП доля видов экономической деятельности с высокой степенью переделов составляет $45,8 \%$, что соответствует уровню Гродненской и Гомельской областей (44,7 и 45,3\%). Кроме того, как показывают результаты разложения процентного прироста ВРП Могилевской области по компонентам национальной и региональной динамики (табл. 1), положительный вклад отраслевого эффекта (0,34 п. п.) свидетельствует об относительно высокой доле в регионе видов деятельности, растущих быстрее, чем те же отрасли по экономике в целом. По нашему мнению, низкий уровень производительности труда в области связан с относительно низкой капиталоемкостью труда, невысоким уровнем используемых производственных технологий и быстро снижающейся фондовооруженностью труда в регионе.

Так, в Могилевской области в 2020 г. на одного занятого приходилось 4,6 тыс. руб. инвестиций в основной капитал, что составляет лишь $67 \%$ от среднего уровня по республике и практически в 2,5 раза меньше, чем в Минской области. При этом в 2014-
2020 гг. в области отмечалось замедление динамики фондовооруженности труда, что привело к снижению доли региона в структуре стоимости основных средств. В условиях низких темпов их технологического обновления в регионе (в 2020 г. коэффициент обновления при среднем по республике уровне $5,4 \%$ составил в области лишь $3,6 \%$ ) это является фактором, сдерживающим рост производительности труда (табл. 6).

Из приведенных в таблице данных обращает на себя внимание высокая доля износа основных средств, особенно его активной части, которая заметно превышает критический уровень экономической безопасности в 40\%. Это создает повышенный риск дальнейшего падения конкурентоспособности производимой в республике продукции, поскольку в условиях замедления инвестиционной активности в стране и при сохранении низкого уровня финансирования расходов на науку и инновации (наукоемкость ВВП в Беларуси в последнее десятилетие не превышала 0,6\% ВВП) крайне сложно переломить складывающиеся негативные тенденции, связанные с утратой позиций обрабатывающей промышленности на мировом рынке. Так, удельный вес Беларуси в мировой добавленной стоимости обрабатывающей промышленности уменьшился с 0,13\% в 2014 г. до 0,096\% в 2019 г. , при этом наиболее значительно

${ }^{7}$ URL: https://stat.unido.org/database/MVA\%202021,\% 20Manufacturing

Таблица 6

Основные параметры использования основных средств по регионам Республики Беларусь, 2014-2020 гг., \%

\begin{tabular}{|c|c|c|c|c|c|c|}
\hline \multirow{3}{*}{ Регион } & \multirow{2}{*}{\multicolumn{2}{|c|}{$\begin{array}{c}\text { Структура первоначальной } \\
\text { стоимости ОС }\end{array}$}} & \multirow{3}{*}{$\begin{array}{c}\text { Темп роста } \\
\text { фондовоору- } \\
\text { женности } \\
\text { труда }\end{array}$} & \multicolumn{3}{|c|}{$\begin{array}{c}\text { Удельный вес накопленной амортизации } \\
\text { на начало } 2020 \text { г. }\end{array}$} \\
\hline & & & & \multirow{2}{*}{ Всего } & \multirow{2}{*}{$\begin{array}{c}\text { Здания } \\
\text { и сооружения }\end{array}$} & \multirow{2}{*}{$\begin{array}{c}\text { Машины } \\
\text { и оборудование }\end{array}$} \\
\hline & 2014 & 2020 & & & & \\
\hline $\begin{array}{l}\text { Республика } \\
\text { Беларусь }\end{array}$ & 100,0 & 100,0 & 115,7 & 44,8 & 39,1 & 53,6 \\
\hline Брестская обл. & 12,7 & 12,2 & 111,9 & 46,8 & 42,0 & 57,4 \\
\hline Витебская обл. & 11,6 & 11,2 & 117,5 & 49,6 & 45,4 & 58,4 \\
\hline Гомельская обл. & 17,5 & 18,7 & 126,9 & 46,4 & 41,5 & 52,9 \\
\hline Гродненская обл. & 10,6 & 10,3 & 115,5 & 43,3 & 39,7 & 50,7 \\
\hline г. Минск & 22,2 & 22,1 & 110,2 & 43,5 & 31,8 & 56,6 \\
\hline Минская обл. & 15,0 & 16,1 & 120,2 & 43,3 & 39,7 & 50,6 \\
\hline Могилевская обл. & 10,4 & 9,4 & 107,0 & 40,8 & 37,1 & 45,9 \\
\hline
\end{tabular}

Источник. Составлено на основе: Регионы Республики Беларусь. Социально-экономические показатели, 2021 (том 1): стат. сборник. 2021. Минск: Национальный статистический комитет Республики Беларусь. 
сократилась доля г. Минска - с 0,027 до 0,019\% и Минской области - с 0,036 до 0,028\%.

Одной из наиболее острых проблем социально-экономического развития Беларуси на региональном уровне является слабая инвестиционная активность, что создает угрозу для устойчивого пространственного развития республики. За 2014-2020 гг. объем инвестиций в основной капитал по стране в целом сократился в реальном выражении на $25 \%$, что соответствует уровню 2008 г. (в сопоставимых ценах). При этом наиболее неблагоприятная ситуация складывается в Могилевской области - темпы снижения инвестиций составили $57,7 \%$, Гомельской - 62,8\%, г. Минске - 63,6\% к уровню 2014 г. (табл. 7). В условиях превышающей нормативные сроки степени износа основных средств это чревато быстрым ухудшением технологического уровня производства, падением деловой активности и способно усилить и без того значительную межрегиональную дифференциацию по общеэкономическому уровню развития регионов.

Наряду со снижающимся объемом инвестиций, дополнительным источником уязвимостей пространственного развития государства является крайне низкая эффективность капитальных вложений, достигающая в Витебской и Могилевской областях отрицательных значений, а также нерациональная технологическая структура инвестиций, характеризующаяся высокой долей строительно-монтажных работ и низким удельным весом затрат на приобретение машин, оборудования, транспортных средств. Так, в 2020 г. доля затрат на строительство зданий и сооружений достигла на уровне республики $52,7 \%$, в том числе в Гомельской области - 59,9\%.

Вместе с тем названные проблемы взаимообуславливают друг друга и тесно связаны со сложившейся моделью финансирования капитальных вложений. В условиях острого недостатка в стране частных инвестиций - их доля в общем объеме инвестиций не превышает 30\% (в 2020 г. $27,6 \%$, в том числе в Гомельской и Гродненской областях - около $20 \%^{8}$ ) - ограниченные финансовые ресурсы государства вынужденно направляются на поддержание функционирования значительно изношенной инфраструктуры регионов, что и определяет недостаточную отдачу капитальных вложений. Несмотря на очевидную сложность решения перечисленных проблем в краткосрочной перспективе, их затягивание чревато нарастанием труднообратимых процессов деградации производственного потенциала и падения конкурентоспособности национальной эконо-

${ }^{8}$ Статистический ежегодник Республики Беларусь, 2021: стат. сборник. 2021. Минск: Национальный статистический комитет Республики Беларусь; Основные показатели деятельности организаций государственного сектора за январь-декабрь 2020 г.: стат. бюллетень. 2021. Минск: Национальный статистический комитет Республики Беларусь.

Таблица 7

Отдельные показатели инвестиционной деятельности по регионам Республики Беларусь, 2014-2020 гг., \%

\begin{tabular}{|l|c|c|c|c|}
\hline \multicolumn{1}{|c|}{ Регион } & $\begin{array}{c}\text { Инвестиции } \\
\text { в основной капитал } \\
\text { на душу населения, } \\
2020 \text { г., руб. }\end{array}$ & $\begin{array}{c}\text { Доля инвестиций } \\
\text { в ВРП в 2020 г., \% }\end{array}$ & $\begin{array}{c}\text { Темп роста } \\
\text { инвестиций в 2020 г. } \\
\text { к уровню 2014 г., \% }\end{array}$ & $\begin{array}{c}\text { Эффективность } \\
\text { инвестиций } \\
\text { в среднем за 2014- } \\
\text { 2020 гг., руб. }\end{array}$ \\
\hline $\begin{array}{l}\text { Республика } \\
\text { Беларусь }\end{array}$ & 3169,5 & 20,2 & 74,9 & 0,017 \\
\hline Брестская обл. & 2488,5 & 23,9 & 80,0 & 0,04 \\
\hline Витебская обл. & 2565,2 & 24,4 & 83,9 & $-0,031$ \\
\hline Гомельская обл. & 3091,4 & 28,0 & 62,8 & 0,004 \\
\hline Гродненская обл. & 3558,3 & 30,5 & 77,6 & 0,011 \\
\hline г. Минск & 2844,4 & 14,1 & 63,6 & 0,026 \\
\hline Минская обл. & 5280,8 & 35,6 & 99,6 & 0,059 \\
\hline Могилевская обл. & 2014,6 & 21,0 & 57,7 & $-0,008$ \\
\hline
\end{tabular}

Источник. Регионы Республики Беларусь. Социально-экономические показатели, 2021 (том 1): стат. сборник. 2021. Минск: Национальный статистический комитет Республики Беларусь. 
мики. Угрозу при этом представляет неизбежно возникающая в условиях недостатка инвестиционных средств проблема ускоренного износа дорожной, транспортной и энергетической инфраструктуры, что значительно усиливает риски техногенных аварий и катастроф.

Названные негативные процессы сопровождаются ухудшением качественных характеристик человеческого развития в регионах, что выражается в первую очередь в усилении дифференциации доходов и относительном снижении уровня жизни населения, консервации структуры их потребительских расходов, сдерживающих прогрессивные преобразования в структуре производства товаров и услуг. Неоднородность распределения экономических ресурсов на территории республики обуславливает пространственную неравномерность динамики реальных денежных доходов населения (разброс темпов их прироста в 2014-2020 гг. составил от 16,7\% в Минске до $-1,9 \%$ в Витебской области), что явилось причиной нарастания межрегионального разрыва в уровне благосостояния населения. Если в 2014 г. расхождение между максимальным значением среднедушевых доходов (г. Минск) и минимальным (Гомельская область) составляло 59,7 п. п., в 2020 г. оно возросло до 67,2 п. п.; разрыв в уровне среднемесячной заработной платы между регионами республики увеличился с 40 до 59,3 п. п. (табл. 8).
В анализируемом периоде заметно сократилось соотношение среднедушевых доходов населения и бюджета прожиточного минимума - в целом по республике с 3,54 в 2014 г. до 3,16 раза в 2020 г., но наиболее значительно - в Витебской области - с 3,14 до 2,65 раза соответственно, Гродненской - 3,36 и 2,83, Могилевской области - 3,1 и 2,6 раза, что свидетельствует об относительном снижении уровня жизни и благосостояния населения. Эти данные корреспондируют с динамикой малообеспеченности населения в региональном разрезе, в том числе ее роста в Витебской области на 0,8 п. п. В целом сохранение высокого уровня бедности в отдельных областях (Гомельская, Брестская область - около 7\%), приближающегося к пороговым значениям экономической безопасности, является источником уязвимости регионального развития, выступая, с одной стороны, фактором усиления миграционных потоков в столичном направлении, а с другой стороны, ограничивая возможности роста экономики за счет низкого потребительского спроса в периферийных регионах. Так, в 2014-2020 гг. душевой уровень потребительских расходов населения на товары в Брестской, Витебской, Гомельской и Могилевской областях составлял 55$60 \%$ от уровня Минска и около $75 \%$ Минской области.

Таблица 8

Динамика заработной платы, денежных доходов и бедности населения в Республике Беларусь, 2014-2020 гг., \%

\begin{tabular}{|c|c|c|c|c|c|c|c|}
\hline \multirow[t]{2}{*}{ Регион } & \multirow[t]{2}{*}{$\begin{array}{c}\text { Темп роста } \\
\text { реальных доходов } \\
\text { населения, } 2020 \text { г. } \\
\text { к уровню } 2014 \text { г. }\end{array}$} & \multicolumn{2}{|c|}{$\begin{array}{c}\text { Денежные доходы } \\
\text { на душу населения, \% } \\
\text { от среднего уровня } \\
\text { по республике }\end{array}$} & \multicolumn{2}{|c|}{$\begin{array}{c}\text { Средняя зарплата, \% } \\
\text { от среднего уровня } \\
\text { по республике }\end{array}$} & \multicolumn{2}{|c|}{$\begin{array}{c}\text { Уровень } \\
\text { малообеспечен- } \\
\text { ности } \\
\text { населения, \% }\end{array}$} \\
\hline & & 2014 & 2020 & 2014 & 2020 & 2014 & 2020 \\
\hline Республика Беларусь & 107,9 & 100,0 & 100,0 & 100,0 & 100,0 & 4,8 & 4,8 \\
\hline Брестская обл. & 105,2 & 84,8 & 83,5 & 87,5 & 84,1 & 6,9 & 6,9 \\
\hline Витебская обл. & 98,1 & 88,7 & 83,9 & 88,2 & 82,8 & 5,8 & 6,6 \\
\hline Гомельская обл. & 104,7 & 84,5 & 82,8 & 93,2 & 86,0 & 7,0 & 6,8 \\
\hline Гродненская обл. & 100,3 & 95,0 & 89,5 & 89,7 & 84,7 & 3,5 & 3,6 \\
\hline г. Минск & 116,7 & 144,2 & 149,7 & 127,7 & 139,8 & 1,0 & 0,9 \\
\hline Минская обл. & 113,8 & 93,3 & 94,8 & 98,9 & 97,5 & 4,3 & 3,9 \\
\hline Могилевская обл. & 100,5 & 86,3 & 82,5 & 87,7 & 80,5 & 6,4 & 6,5 \\
\hline $\begin{array}{l}\text { Расхождение } \\
\text { (max-min), п. п. }\end{array}$ & - & 59,7 & 67,2 & 40,0 & 59,3 & 6,0 & 6,0 \\
\hline
\end{tabular}

Источник. Рассчитано на основе: Регионы Республики Беларусь. Социально-экономические показатели, 2021 (том 1): стат. сборник. 2021. Минск: Национальный статистический комитет Республики Беларусь. 


\section{Межрегиональная дифференщиация} как источник уязвимости экономики

Совокупность перечисленных проблем и пространственных диспропорций находит свое концентрированное выражение в усилении межрегиональной дифференциации по общему уровню сочиально-экономическо20 развития, что представляет собой самостоятельный вызов для устойчивого роста регионов. Вместе с тем оценка уровня дивергенции между регионами сопряжена с рядом методологических и методических проблем. Результаты сопоставлений могут существенно отличаться в зависимости от состава анализируемых показателей (финансовые, макроэкономические, социальные); выбора метода оценки и способа расчета показателей - в текущих или сопоставимых ценах, совокупный объем или на душу населения; сравнения по скорости изменения параметров (темпов роста/снижения) или их уровня в абсолютном выражении. При этом следует учитывать, что не всегда уменьшение межрегиональной дифференциации свидетельствует о позитивных изменениях в экономике, поскольку процессы сближения и выравнивания уровня развития территорий могут сопровождаться замедлением экономической динамики и быть вызваны, например, опережающим спадом в наиболее развитых регионах (Казанцев, 2008).

Для оценки уровня межрегиональной дифференциации в Республике Беларусь в 2014-2020 гг. по ряду важнейших социально-экономических параметров нами были рассчитаны соотношения (разрывы) между максимальными (лучшими) и минимальными (худшими) в региональном разрезе значениями показателей социально-экономического развития, представленных в текущих ценах в расчете на душу населения (рис. 3).

Проведенный анализ свидетельствует об усилении дивергенции между регионами по ключевым экономическим параметрам, при этом особенно сильно разрыв увеличился по заработной плате и инвестициям в основной капитал. Но вместе с тем тенденцию к сближению демонстрируют показатели экспорта товаров и услуг, а также промышленного производства - соотношение регионов уменьшилось с 4,18 в 2014 г. до 4,12 раза в 2020 г. и с 1,95 до 1,7 раза соответственно. Однако еще в предкризисном 2019 г. отмечалось сохранение высокой дифференциации между регионами по объему промышленного производства - 1,93 раза и ее усиление по экспорту- до 4,74 раза. Уменьшение соотношения названных показателей в 2020 г. было обусловлено особенностями делового цикла - сокращением внешнего спроса в результате пандемии коронавируса и соответствующим снижением объемов производства в республике.

Для корректной оценки уровня межрегиональной дифференциации, предполагающей нивелирование влияния ценового фактора, исследуемые показатели были переведены в постоянные цены 2020 г. Анализ дан-

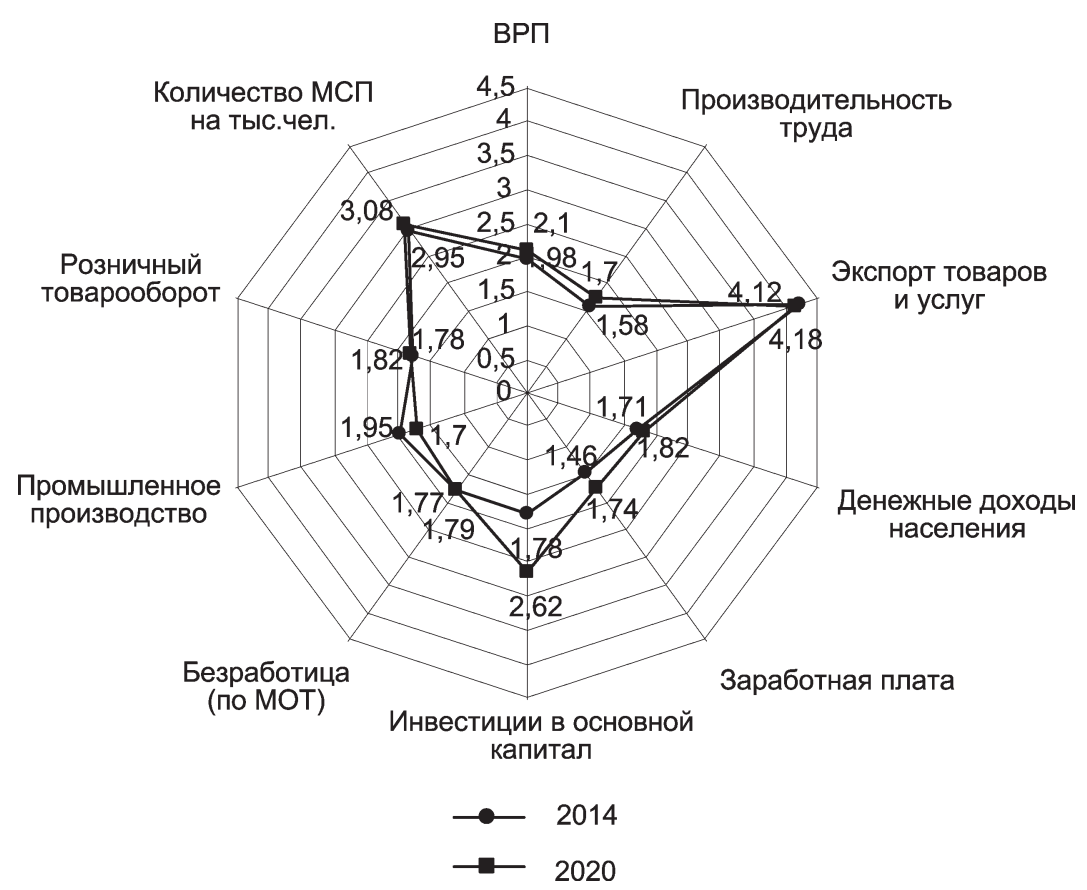

Рис. 3. Разрыв в уровне отдельных социально-экономических показателей между регионами Республики Беларусь, 2014-2020 гг., в расчете на душу населения, в текущих ценах, раз

Источник. Рассчитано на основе: Регионы Республики Беларусь. Социально-экономические показатели, 2021 (том 1): стат. сборник. 2021. Минск: Национальный статистический комитет Республики Беларусь. 
ных в сопоставимых ценах (рис. 4) свидетельствует о нарастании дивергенции между регионами по уровню денежных доходов, заработной платы, инвестиций в основной капитал. В то же время производительность труда, уровень ВРП и розничный товарооборот на душу населения демонстрируют незначительно выраженную тенденцию к уменьшению межрегиональной дифференциации. Однако ее снижение в основном вызвано действием ряда негативных факторов - опережающим сокращением динамики экономического роста в регионах-лидерах по сравнению с отстающими. Так, в период 2014-2020 гг. ВВП республики в расчете на душу населения увеличился в реальном выражении в 1,01 раза, при этом наиболее сильное сокращение душевого объема ВРП отмечалось в г. Минске - темп снижения в 2020 г. составил 95,9\% к уровню 2014 г. Сделанный ранее вывод о сохранении и усилении разрыва в уровне общеэкономического развития на региональном уровне подтверждает также увеличение соотношения по валовому объему ВРП в сопоставимых ценах между регионами с 4,11 раза в 2014 г. до 4,16 раза в 2020 г.

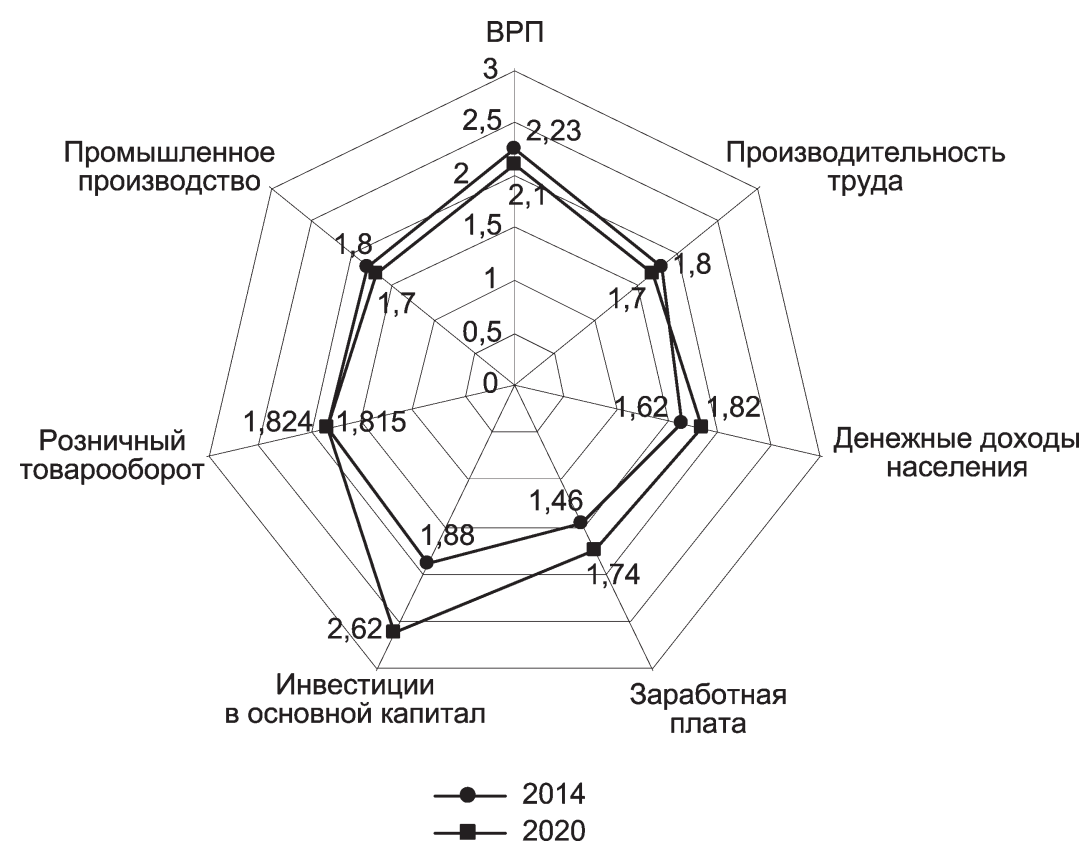

Рис. 4. Разрыв в уровне отдельных социально-экономических показателей между регионами Республики Беларусь, 2014-2020 гг., в расчете на душу населения, в постоянных ценах, раз

Источник. Рассчитано на основе: Регионы Республики Беларусь. Социально-экономические показатели, 2021 (том 1): стат. сборник. 2021. Минск: Национальный статистический комитет Республики Беларусь.
Усиление процессов региональной дивергенции по ряду важнейших социальноэкономических показателей в текущих и сопоставимых ценах свидетельствует о недостаточной результативности проводимой региональной политики. Это порождает широкий спектр рисков и уязвимостей, связанных с постоянным воспроизводством и усилением негативных последствий действующего механизма межрегиональной дифференциации.

Вместе с тем полностью устранить неравенство между регионами в принципе невозможно и вряд ли целесообразно: важно не допускать чрезмерной пространственной асимметрии, приводящей к торможению экономического роста в стране. При этом возникает закономерный вопрос - где та граница, которая свидетельствует о чрезмерном нарастании региональной дифференциации?

Международные сравнения показывают, что уровень межрегиональных различий в разрезе укрупненных территориальных образований в Беларуси, составляющий по среднедушевому объему ВВП 2,1 раза, не является критическим и в целом соответствует уровню европейских стран, активно проводящих политику выравнивания пространственного развития. По данным за 2019 г., разрыв между регионами в Чехии по среднедушевому объему ВВП составил 2,7, Франции - 2,4, Германии - 2,3, Нидерландах - 1,95, Испании - 1,9, Литвы - 1,8, Швеции 1,7 раза. При этом в Беларуси уровень дивергенции между регионами по ВВП на душу населения значительно ниже по сравнению с Китаем - 4,8 раза и Россией - 5,2 раза 9 . В целом для больших и экономически разреженных территорий обычно характерен более высокий уровень неравенства (Минакир, 2020).

${ }^{9}$ URL: http://appsso.eurostat. ec.europa.eu/nui / submitView TableAction.do; URL: https://rosstat. gov.ru/storage/mediabank/LkooETqG/ Region_Pokaz_2020.pdf 
Вместе с тем в соответствии с подходом, применяемым в Европейском Союзе (ЕС) для отнесения регионов к проблемным, когда душевой уровень ВРП территории составляет менее $75 \%$ от среднего по ЕС в целом (по паритету покупательной способности), в ЕС в депрессивных регионах проживает в среднем около $25 \%$ населения ${ }^{10}$. Применение данного подхода на национальном уровне (в рамках стандарта NUTS 2) в отдельных странах показывает, что доля населения, проживающего в регионах, ВРП которых ниже среднедушевого уровня по стране в целом более чем на $25 \%$, колеблется от нуля в странах, которым удалось преодолеть значительные межрегиональные различия (Финляндия, Швеция), до $30-50 \%$ в государствах со значительной дифференциацией пространственного развития: в Турции - 33, России - 38 , Болгарии $-49,6 \%$ (рис. 5 ).

10 По оценкам, в 2020 г., после выхода Великобритании из ЕС, доля населения Евросоюза, проживающего в депрессивных регионах, составит около 28\%. URL: http:// appsso.eurostat.ec.europa.eu/nui/submitViewTableAction.do; URL: https://rosstat.gov.ru/storage/mediabank/LkooETqG/ Region_Pokaz_2020.pdf
В то же время расчеты показывают, что в Республике Беларусь в проблемных регионах, наиболее серьезно отстающих от среднереспубликанского уровня, проживает $62,7 \%$ населения республики, что заметно превышает аналогичный показатель в России и европейских странах и свидетельствует об относительно низком уровне жизни большей части населения страны.

Высокая неравномерность пространственного распределения благосостояния на долю 37,3\% населения Беларуси, проживающего в г. Минске и Минской области, приходится свыше $50 \%$ ВВП ${ }^{11}$, создаваемого в стране, - является одним из факторов усиления социального неравенства и замедления экономического роста. В условиях глубоких региональных диспропорций и концентрации значительной части доходов экономики у трети населения предпринимаемые попытки стимулирования экономического роста приводят к неравномерному и непропорциональному воздействию на уровень и структуру

11 Точная оценка доли ВВП зависит от способа распределения его нераспределенной части, которая составляет в Беларуси около $15 \%$ ВВП.

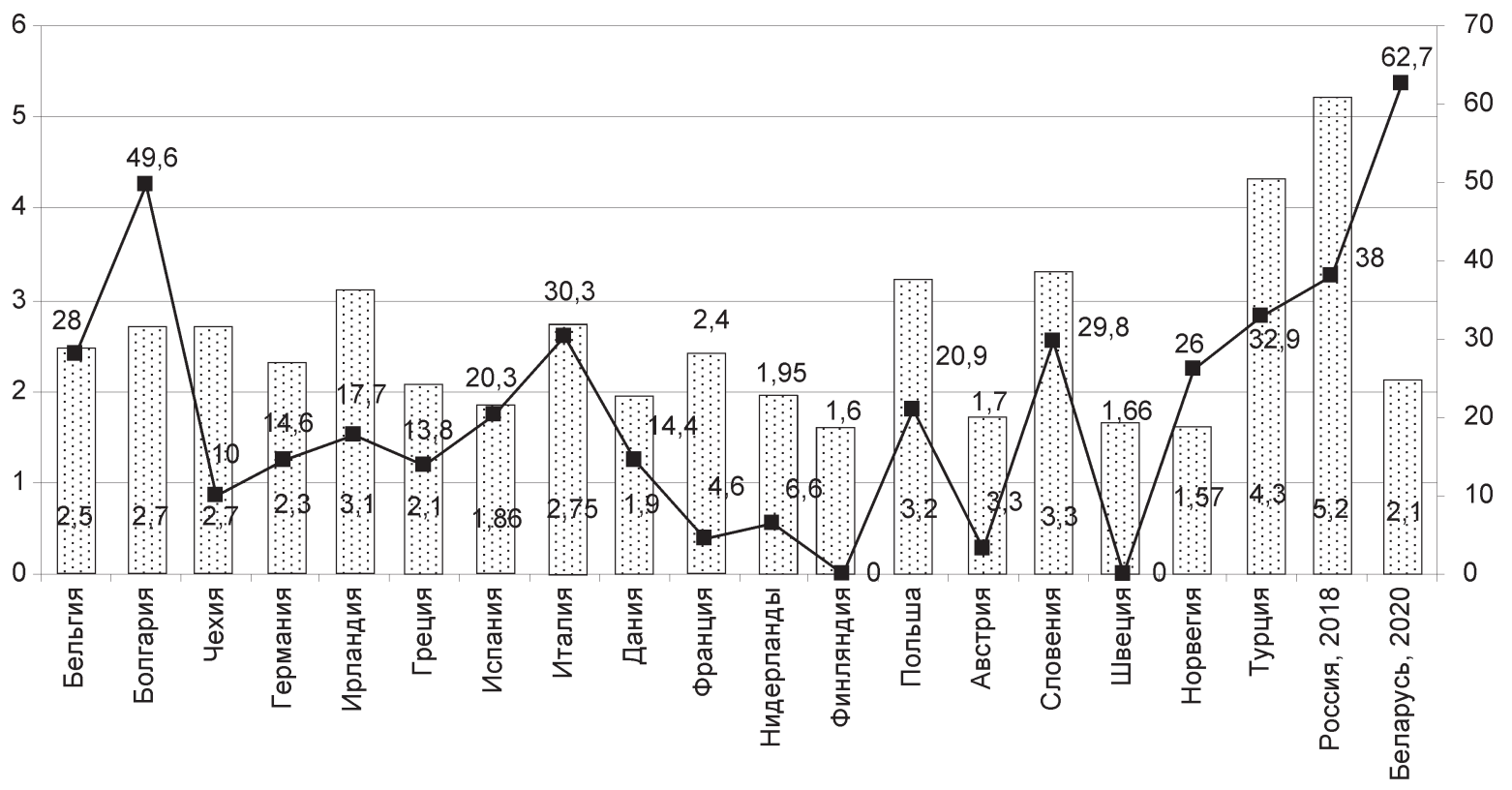

Соотношение максимального и минимального уровней среднедушевого ВРП по регионам, раз

-2 Доля населения страны, проживающего в проблемных регионах, \% от общей численности (правая шкала)

Рис. 5. Показатели уровня межрегиональной дифференциации по отдельным странам, 2019 г.

Источник. Рассчитано на основе: URL: http://appsso.eurostat.ec.europa.eu/nui/submitViewTableAction.do; URL: https://rosstat.gov.ru/storage/mediabank/LkooETqG/Region_Pokaz_2020.pdf; URL: https:// www.belstat.gov.by/ofitsialnaya-statistika/publications/izdania/public_compilation/index_18078/ 
совокупного спроса в региональном разрезе, что сдерживает результативность мер экономической политики.

Накопленные пространственные диспропорции и усиление дифференциации в уровне социально-экономического развития между регионами наряду с недостаточной результативностью мер региональной политики обостряют риски, связанные с замедлением роста и потерей конкурентоспособности экономики, постепенным исчерпанием потенциала человеческого развития и обрекают страну на долгосрочное отставание от развитых стран. Поэтому региональная политика, направленная на снятие пространственных ограничений экономического развития страны, призвана играть важную роль в реализации политики роста национальной экономики.

В настоящее время Программой социально-экономического развития на 20212025 гг., Программой деятельности Правительства Республики Беларусь на период до 2025 года ${ }^{12}$ запланирована реализация комплекса мер в области регионального развития, направленная на повышение привлекательности территорий, расположенных за пределами столицы и областных центров. Они предусматривают: стимулирование ускоренного развития районов и городов с численностью населения 80 тыс. чел. и более; точечные меры поддержки и стимулирования в зависимости от специализации, компетенций и потенциала территорий; создание комфортной и безопасной среды проживания; обеспечение транспортной доступности территорий, качественное улучшение коммунальной инфраструктуры и т. д. Основным инструментом достижения поставленных задач выступает реализация инвестиционных проектов, предусматривающих создание кластеров и технопарков, индустриальных площадок и т. д.

Однако, учитывая масштабность и глубину проблемы несбалансированного пространственного развития в Беларуси, запланированная реализация мер по выравниванию социально-экономического развития тер-

${ }_{12}$ URL: https://www.economy.gov.by/uploads/files/ macro-prognoz/PSM-758.pdf; URL: https://economy.gov.by/ uploads/files/macro-prognoz/Ukaz-292-1.pdf риторий преимущественно на основе инструментов инвестиционной политики вряд ли принесет желаемую отдачу. Мировой опыт показывает, что сближение уровней регионального развития достигается в основном в условиях ускоренного роста национальной экономики, когда «прилив поднимает все лодки». Это обуславливает необходимость комплексного подхода к решению проблем пространственного развития экономики, увязывающего воедино меры региональной, макроэкономической, структурной и институциональной политики.

Перспективные меры пространственного развития государства должны предусматривать, во-первых, дифференцированный подход к развитию территорий с учетом имеющихся конкурентных преимуществ регионов, сложившейся специализации и накопленных компетенций и, во-вторых, сочетание мер государственной поддержки и развитие собственного экономического потенциала регионов. Требуются разработка и реализация комплекса мер, направленных на повышение конкурентоспособности регионов как источника роста конкурентоспособности страны. Это обуславливает необходимость, во-первых, формирования стратегии пространственного развития республики, содержащей общие инструменты и механизмы ее реализации, точки роста и приоритеты территориального развития, увязанные с перспективными структурными преобразованиями в экономике и отраслевыми приоритетами. Во-вторых, необходимо определить местные стратегии развития регионов, которые не имели бы формального «программного» характера, были разработаны с обязательным привлечением представителей научной и деловой общественности и учитывали особенности местной ресурсно-сырьевой базы, протекающие демографические процессы, имеющиеся проблемы и возможности развития. Это способствовало бы, с одной стороны, реализации государственных приоритетов развития на местном уровне, а с другой - согласованию интересов общества, бизнеса и государства в решении региональных проблем.

Вследствие недостатка частных инвестиций в стране и регионах приоритетным направлением экономической политики должны стать стимулирование деловой актив- 
ности и формирование благоприятного бизнес-климата, что требует пересмотра на государственном уровне общей концепции управления развитием предпринимательства и частного сектора. Достижение этой цели обуславливает необходимость развития и усиления роли местного управления и самоуправления, что позволило бы местным властям самостоятельно создавать благоприятные условия, в том числе в части налогового стимулирования, и конкурировать с другими регионами за привлечение инвестиционного и предпринимательского капитала в рамках единых для государства отраслевых приоритетов. Важнейшими инструментами конкурентной борьбы регионов за инвестиции должны выступать минимизация бюрократических и административных барьеров, облегчение доступа предпринимателей к объектам инфраструктуры.

В условиях острой нехватки государственных финансовых средств недопустимо их неэффективное использование. Необходимо, во-первых, предусмотреть реализацию инвестпроектов с высокой отдачей и относительно короткими сроками окупаемости, обеспечивающих производство востребованной на рынке продукции и ориентированных преимущественно на местные источники сырья, а во-вторых, обеспечить концентрацию инвестиционных ресурсов государства на реализации масштабных инфраструктурных проектов в регионах, которые позволили бы решить проблему «привязки» населения к данной территории и создать в регионе рабочие места.

Учитывая высокий уровень межрегиональной дифференциации доходов населения и нарастание тенденций относительного снижения уровня жизни в отстающих регионах, следует пересмотреть подходы в области политики оплаты труда и роста доходов на региональном уровне. В условиях сложившегося в отдельных областях низкого объема потребления товаров и услуг политика стимулирования доходов населения обладает мощным потенциалом ускорения роста экономики и позволяет смягчить проблему малообеспеченности домохозяйств.

Политика ускоренного роста доходов населения в отстающих регионах выступает инструментом привлечения частных инвес- тиций, подавая инвесторам сигнал о расширении внутреннего рынка и позволяя стимулировать сбережения населения, способные при благоприятных условиях трансформироваться в инвестиции. Для решения этой задачи необходимо предусмотреть введение в проблемных регионах (районах) повышающих коэффициентов к заработной плате или выплат стимулирующего характера, усилить контроль за обеспечением минимальных социальных стандартов, особенно в части выплат заработной платы на уровне не ниже минимальной. В случае возобновления практики на республиканском уровне привязки роста заработной платы к темпам роста производительности труда важно предусмотреть для отстающих регионов более высокое соотношение названных параметров.

Таким образом, смягчению негативных последствий усиления пространственных диспропорций и чрезмерной межрегиональной дифференциации в республике должны способствовать меры в области стратегического планирования пространственного развития; политики в области роста доходов и благосостояния населения, особенно в отстающих регионах; стимулирования частных инвестиций. Однако данные меры должны быть взаимоувязаны и скоординированы с мерами макроэкономического и институционального характера, политикой структурных преобразований и иметь комплексный характер, обеспечивающий их последовательную и системную реализацию.

\section{СПИСОК ЛИТЕРАТУРЫ (REFERENCES)}

Берченко Н.Г. 2020. Стратегические ориентиры регионального развития Республики Беларусь. Экономический бюллетень Научно-исследовательского экономического института Министерства экономики Республики Беларусь. № 5. C. 4-14. [Berchenko N. 2020. Strategic guidelines for regional development of the Republic of Belarus. Ekonomicheskiy byulleten' Nauchnoissledovatel'skogo ekonomicheskogo instituta Ministerstva ekonomiki Respubliki Belarus'. No 5. PP. 4-14. (In Russ.)]

Казанцев С.В. 2008. Оценка взаимного положения регионов. Регион: экономика и соииология. № 2. C. 151-174. [Kazantsev S.V. 2008. Comparative assessment of regional economies. 
Region: ekonomika i sotsiologiya. No 2. PP. 151174. (In Russ.)]

Крюков В.А., Коломак Е.А. 2021. Пространственное развитие России: основные проблемы и подходы к их преодолению. Научные труды Вольного экономического общества России. № 1. Т. 227. C. 92-114. [Kryukov V.A., Kolomak E.A. 2021. Spatial development of Russia: Main problems and approachesto the solution. Nauchnye trudy Vol'nogo ekonomicheskogo obshchestva Rossii. No 1. Vol. 227. PP. 92-114. (In Russ.)]

Минакир П.А. 2019. Российское экономическое пространство: стратегические тупики. Экономика реzиона. Т. 15. № 4. C. 967-980. [Minakir P.A. 2019. Russian economic space: Strategic impasses. Ekonomika regiona. Vol. 15. No 4. PP. 967-980. (In Russ.)]

Минакир П.А. 2020. Стратегия пространственного развития Российской Федерации на период до 2025 года: политическая реакция на вызовы на XXI века. Вызовы и политика пространственного развития России в XXI веке. Москва: Товарищество научных изданий КМК. [Minakir P.A. 2020. Spatial development strategy of the Russian Federation until 2025: Political response to the challenges of the 21st Century. Vyzovy i politika prostranstvennogo razvitiya Rossii v XXI veke. Moscow: Tovarishchestvo nauchnykh izdaniy KMK. (In Russ.)]

Михеева Н.Н. 2013. Структурные факторы региональной динамики: измерение и оценка. Пространственная экономика. № 1. С. 11-32. [Mikheeva N.N. 2013. Structural factors of regional dynamics: Measuring and assessment. Prostranstvennaya ekonomika. No 1. PP. 11-32. (In Russ.)]

Фатеев В.С. 2012. Развитие регионов и городов в Республике Беларусь: проблемы, тенденции, направления совершенствования государственного регулирования. Регионалистика. Гродно: ГрГУ им. Я. Купалы. С. 17-36. [Fateev V.S. 2012. Development of regions and cities in Belarus: problems, trends, direction of improving state regulation. Regionalistika. Grodno: GrGU im. Ya. Kupaly. PP. 17-36. (In Russ.)]

Knudsen D.C. 2000. Shift-Share Analysis: Further Examination of Models for the Description of Economic Change. Socio-Economic Planning Sciences. Vol. 34. Iss. 3. PP. 177-198.

Mondal W.I. 2009. An Analysis Of The Industrial Development Potential Of Malaysia: A Shift-Share Approach. Journal of business \& Economic Research. Vol. 7. No 5. PP. 41-46. URL: https://clute journals.com/index.php/JBER/article/view/2289/2337

\title{
REGIONAL IMBALANCES AND RISKS OF SPATIAL DEVELOPMENT IN THE REPUBLIC OF BELARUS
}

\section{Ekaterina Rozhkovskaya ${ }^{1}$}

\author{
Author affiliation: ${ }^{1}$ Belarus State Economic University (Minsk, Belarus). \\ Corresponding author: Ekaterina Rozhkovskaya (E.Rozhkovskaya@mail.ru).
}

ABSTRACT. The article examines the main imbalances and problems of the spatial development of the Belarusian economy in 2014-2020. It is noted that the existing regional imbalances and increasing differentiation between regions in terms of socio-economic development are a serious risk factor for increasing social inequality in the country and slowing down economic dynamics in the short and long term. The main directions in the field of regional economic policy are suggested, which make it possible to reduce the existing spatial imbalances and gaps in the level of development of the regions of Belarus.

KEYWORDS: Belarusian economy, regions, regional imbalances, gross regional product, risks of spatial development, regional policy.

JEL-code: R10, R12, R58, E61.

DOI: $10.46782 / 1818-4510-2021-4-55-71$ 